\title{
SECOND SCHOLASTICISM AND BLACK SLAVERY ${ }^{1}$
}

\author{
Segunda Escolástica e escravidão negra \\ La Segunda Escolástica y la esclavitud negra
}

Roberto Hofmeister Pich²

Pontifícia Universidade Católica do Rio Grande do Sul, Porto Alegre, RS, Brasil

\begin{abstract}
In order to systematically explore the normative treatment of black slavery by Second Scholastic thinkers, usually placing the problem within the broad discussion of moral conscience and, more narrowly, the nature and justice of trade and contracts, I propose two stations of research that may be helpful for future studies, especially in what concerns the study of Scholastic ideas in colonial Latin America. Beginning with the analysis of just titles for slavery and slavery trade proposed by Luis de Molina S.J. (1535-1600), I show how his accounts were critically reviewed by Diego de Avendaño S.J. (1594-1688), revealing basic features of Second Scholastic normative thinking in Europe and the Americas. Normative knowledge provided by these two Scholastic intellectuals would be deeply tested throughout the last decades of the $17^{\text {th }}$ century, especially by authors who sharpened the systemic analysis and a rigorist moral assessment of every title of slavery and slaveholding, as well as the requirements of an ethics of restitution.
\end{abstract}

Keywords: black slavery, Second Scholasticism, commutative justice, probabilism, Luis de Molina, Diego de Avendaño.

\footnotetext{
1 This study was prepared during a stay as guest professor at the Rheinische Friedrich-WilhelmsUniversität Bonn / Germany, as first "CAPES / Universität Bonn Lehrstuhlinhaber", from July 2018 to February 2019. I hereby express my gratitude to the remarkable support of the Brazilian Agency Coordenação de Aperfeiçoamento de Pessoal de Nível Superior (Coordination for the Improvement of Higher Education Personnel) and the University of Bonn.

2 Professor nos Programas de Pós-Graduação em Filosofia e Programa de Pós-Graduação em Teologia da PUCRS. Pesquisador do CNPq, Nível 1D. E-mail: roberto.pich@pucrs.br; roberto. pich@pq.cnpq.br. ORCID: http://orcid.org/o0oo-0001-5770-3522
} 


\section{Resumo}

No intuito de explorar sistematicamente o tratamento normativo da escravidão negra por pensadores da Segunda Escolástica, que normalmente colocam o problema dentro da discussão ampla da consciência moral e, mais em específico, da natureza e da justiça do comércio e dos contratos, eu proponho duas estações de pesquisa que podem ser de ajuda para estudos futuros, em especial no que diz respeito ao estudo de ideias escolásticas na América Latina colonial. Começando com a análise dos títulos justos em favor da escravidão e do comércio de escravos propostos por Luis de Molina S. J. (1535-1600), eu procuro mostrar como os seus relatos foram recebidos criticamente por Diego de Avendaño S. J. (1594-1688), revelando traços básicos do pensamento normativo da Segunda Escolástica na Europa e nas Américas. O conhecimento normativo oportunizado por esses dois intelectuais escolásticos seria testado de forma profunda ao longo das últimas décadas do século 17 , sobretudo por autores que aguçaram a análise sistêmica e a avaliação moral rigorista de todos os títulos de escravidão e de posse de escravos, bem como as exigências de uma ética da restituição.

Palavras-chave: escravidão negra, Segunda Escolástica, justiça comutativa, probabilismo, Luis de Molina, Diego de Avendaño.

\section{Resumen}

Con el fin de explorar sistemáticamente el tratamiento normativo de la esclavitud negra por parte de los pensadores que suelen poner el problema de la Segunda Escolástica de dentro de la amplia discusión de la conciencia moral y, más concretamente, de la naturaleza y la justicia del comercio y de los contratos, propongo dos estaciones de investigación que pueden ser de ayuda para futuros estudios, especialmente con respecto al estudio de las ideas escolásticas en la América Latina colonial. Comenzando con el análisis de los justos títulos a favor de la esclavitud y el comercio de esclavos propuesto por Luis de Molina S. J. (1535-1600), trato de mostrar cómo sus relatos fueron recibidos críticamente por Diego de Avendaño S. J. (1594-1688), revelando rasgos fundamentales de la Segunda Escolástica, del pensamiento normativo en Europa y en las Américas. El conocimiento normativo de estos dos intelectuales escolásticos sería proporcionado en las últimas décadas del siglo XVII, especialmente por autores que agudizaron el análisis sistémico y la evaluación moral rigorista de todos los títulos de la esclavitud y la posesión de esclavos, así como las exigencias de una ética de restitución.

Palabras clave: esclavitud negra, Segunda Escolástica, justicia conmutativa, probabilismo, 


\section{Introduction, or: A Historical-Philosophical Overview of Slavery}

This study has as a central concern philosophical, along with legal and theological, assessments of a particular form of slavery - black slavery - regrettably practiced in the Western World and in particular in Latin America, in the period that stretches from the $16^{\text {th }}$ up to the $19^{\text {th }}$ century. More specifically, the focus of the study is the investigation of authors and works that represent views of "Second Scholasticism" 3 broadly speaking, and of Iberian-Salmantine Scholasticism more narrowly, including here the influence of their approaches in Latin American Scholastic thinkers ${ }^{4}$. In fact, there is still a notorious lack of philosophical studies dealing with such authors and works, examining the main lines of their normative considerations on black slavery ${ }^{5}$.

Surely, what Iberian and Latin American Scholastic authors wrote on slavery and black slavery relies very much on ancient, patristic and medieval philosophical arguments and on the traditional views of Roman and Canon law on the core topic. Still, we should pay attention not only to reception, but also to developments and criticisms of those doctrines, particularly because of the connection of ancient and medieval views with the discussions on the human status of original inhabitants in the American continent ${ }^{6}$ and in (Black or roughly Sub-Saharan) Africa ${ }^{7}$, on the establishment of slavery that

3 On this concept, cf. R. H. Pich, An Index of 'Second Scholastic' Authors, in: A. S. Culleton and R. H. Pich (eds.), Right and Nature in the First and Second Scholasticism, p. IX-XIV.

4 On Latin American Scholasticism, see W. B. Redmond, Bibliography of the Philosophy in the Iberian Colonies of America, 1972; W. B. Redmond, Latin America, Colonial Thought, in: E. Craig (ed.), The Routledge Encyclopedia of Philosophy, p. 421-426; R. H. Pich and A. S. Culleton, SIEPM Project "Second Scholasticism": Scholastica colonialis, in: Bulletin de Philosophie Médiévale, p. 25-45.

5 Cf. R. H. Pich - A. S. Culleton - A. C. Storck, Second Scholasticism and Black Slavery - Some Philosophical Assessments, in: Patristica et Mediaevalia, p. 3-13.

6 Cf. the classical treatment by Francisco de Vitoria, De los índios recientemente descubiertos (relección primera) - De indis recenter inventis relectio prior, in: Obras de Francisco de Vitoria - Relecciones teologicas, p. 641-726.

7 On this subject, cf., for example, R. H. Pich, Religious Language and the Ideology of Black Slavery: Notes on Alonso de Sandoval's De instauranda Aethiopum salute, in: Filosofia Unisinos - Unisinos Journal of Philosophy, p. 218-220. 
resulted as an effect of wars claimed as just ${ }^{8}$, on the religious and cultural ideologies of salvation and civilizational supremacy that allowed for slavery condition ${ }^{9}$, and on the economic concerns of the Western World - i.e., European potencies - in particular that legitimized the servitude and the Atlantic slave trade of Africans to the "New World" as a whole".

As it is well known, enslavement and slavery societies were widespread in the ancient world" - not to mention the fact that we find positions favorable to slavery in the Christian Scriptures ${ }^{12}$. And yet, there is no doubt that the ancient classical view on slavery that is most impactful on the history of philosophy - at least, until the $16^{\text {th }}$ century - is the one advanced by Aristotle ${ }^{13}$. Although one should recognize that Plato accepted slavery - even affirming that a true slave is a person who has a lack of reason (Laws 966b) ${ }^{14}$ - and included slaves in his account of constitutional ideal states (Republic 433e; Laws 773e) ${ }^{15}$, it was Aristotle who offered in his Politics the first detailed grounding of such a condition ${ }^{16}$. He proposed a theory of natural slavery.

8 Cf. Francisco de Vitoria, De los índios, o del derecho de guerra de los españoles sobre los bárbaros (relección segunda) - De indis, sive de iure belli hispanorum in barbaros, relectio posterior, in: Obras de Francisco de Vitoria - Relecciones teologicas, p. 811-858. Cf. footnote 25, below.

9 Two different examples are Juan Ginés de Sepúlveda, Demócrates Segundo o de las justas causas de la guerra contra los índios, especially Book I, p. 3-85 (on the enslavement of the aboriginal inhabitants of the Americas); and Alonso de Sandoval, Un tratado sobre la esclavitud - De instauranda Aethiopum salute, above all Books II-III, p. 231-503 (on the slavery condition and evangelization of the blacks).

10 Cf. footnotes 34, 36 and 37, below.

$"$ See, for example, H. Wallon, Histoire de l'esclavage dans l'antique, Vols. 1-3, 1847; R. Schlaifer, Greek Theories of Slavery from Homer to Aristotle, in: M. I. Finley (ed.), Slavery in Classical Antiquity, p. 165-204; D. B. Davis, The Problem of Slavery in Western Culture, p. 29-90.

12 See, for example, W. Dietrich, Sklaverei I. Altes Testament, in: Theologische Realenzyklopädie, p. 367-373; Ch. Kähler, Sklaverei II. Neues Testament, in: Theologische Realenzyklopädie, p. 373-377.

13 On this aspect of the reception of Aristotle in Latin America and Second Scholasticism, cf. L. Hanke, Aristóteles e os índios americanos, 1955; L. Hanke, The Spanish Struggle for Justice in the Conquest of America, 1965; G. Tosi, La teoria della schiavitù naturale nel debattito sul Nuovo Mondo (1510-1573): "Veri domini" o "servi a natura"?, 2002.

14 See Platon, Gesetze, XII, 966b, p. 515-517.

15 See Platon, Der Staat, IV, 433e, p. 154; Platon, Gesetze, VI, 773e, p. 204-205. See also E. Schütrumpf, Aristotle's Theory of Slavery - A Platonic Dilemma, in: Ancient Philosophy, p. 111-123.

16 The classical treatment appears in Aristotle, Politics (transl. by B. Jowett), I 4-13, p. 1131-1146. See also M. Schofield, Ideology and Philosophy in Aristotle's Theory of Slavery, in: G. Patzig 
In Book I of his Politics Aristotle defends slavery as a derivative social institution. It was not only - and primarily - a political and legal creation, but fundamentally an institution based on nature itself. There are "natural slaves"17, and so slavery is or can be natural. A human being is a slave by nature because of his / her lack of reason. Aristotle affirms that a slave by nature is one who "has no deliberative faculty at all"18, and the best he / she can be in order to fulfill his / her nature is to become - under a relationship of subjection - no more than "a living but separated part of his [the master's] bodily frame"19. As an institution that sets up a particular form of social relationship, slavery, thus, brings benefits both to the master, who profits from the instrumental labor of the natural slave and can then dedicate himself to political activity and virtue, fulfilling his natural telos, and to the slave him / herself, who can then be affected by the "deliberative ability" of the slaveholder ${ }^{20}$. The slaveholder is, thus, the external ruler of the slave ${ }^{21}$, he has complete natural authority over him / her and, as the only one in the complementary (but unitary) relationship who has full human logos, he disciplines and admonishes the slave according to the level of deficiency in reason of the later ${ }^{22}$. Aristotelian slavery is a form of bios for the living beings that do not realize their nature according to the completeness of their specific form which is the human life - and so such a life will never possibly turn, strictly speaking, into a bios politikos ${ }^{23}$. Curiously

(Hrsg.), Politik, p. 1-27; N. D. Smith, Aristotle's Theory of Natural Slavery, in: D. Keyt and F. D. Miller, Jr. (eds.), A Companion to Aristotle's Politics, p. 142-155; P. Pellegrin, Natural Salvery, in: M. Deslauriers and P. Destrée (eds.), The Cambridge Companion to Aristotle's Politics, p. 92-116.

17 Aristotle, Politics I 4-7, p. 1131-1135; I 5, 1254a21-24, p. 1132.

18 Aristotle, Politics I 13, 1260a12, p. 1144.

19 Aristotle, Politics 16, 1255 b11-12, p. 1134.

20 Aristotle, Politics I 4, 1254a14-, pp. 1131-1132; I 13, 126oa33-36, p. 1145. See also O. Höffe, Aristoteles, p. 255-257.

${ }^{21}$ See N. L. Brugnera, A escravidão em Aristóteles, p. 79-83.

22 Aristotle, Politics I 13, 1260b5-7, p. 1145.

23 We could discuss whether this brings as a result an account of two different "human species"; see N. L. Brugnera, A escravidão em Aristóteles, p. 105-112. 
enough, any other form of "conventional" or "legal-political" slavery - i.e., of slavery institution and systems based on customary and positive law - was viewed by Aristotle as unnatural and morally wrong ${ }^{24}$. Though historically unsurprising, it is interesting to realize that such an influential critic of the theory of natural slavery as the Salmantine master, Francisco de Vitoria O.P. (1483-1546), could nonetheless accept forms of slavery, being the most explicit one slavery as a consequence of corrective justice after a war justly waged 25 . Other kinds of civil-legal slavery will be considered below.

Truly, the universe of sources of philosophical and theological views on slavery, known and more or less shared by Second Scholastic authors, also embraces the accounts given by Fathers of the Church, particularly by Augustine, who combined an account of differences among human beings with the biblical idea of sin as a cause of slavery ${ }^{26}$. We should mention that a thinker as devoted to natural law theory as Thomas Aquinas - who seems to recognize, in line with the Stoic ius naturale, based on natural equality, original freedom for all human beings - accepted slavery according to the ius gentium ${ }^{27}$. Even more than that, we find in Aquinas both sympathy for an Aristotelian theory of hierarchical subjection - particularly in his account of a part of the ius gentium as an addition to natural law and natural justice or having to do with a derivative meaning of it in terms of

24 Aristotle, Politics, I6, pp. 1133-1135; VII 3, pp. 1281-1282; VII 10, pp. 1290-1292. One should also mention the Aristotelian idea of "functional slavery" - a political slavery -, that is, of "artisans" in ancient Greece; see N. L. Brugnera, A escravidão em Aristóteles, p. 77-83.

25 Francisco de Vitoria, De indis, sive de iure belli hispanorum in barbaros, relectio posterior, §§ 38-43, p. 843-847. See also R. H. Pich, Dominium e ius: sobre a fundamentação dos direitos humanos segundo Francisco de Vitoria (1483-1546), in: Teocomunicação, p. 401.

26 Agostinho, A cidade de Deus contra os pagãos (De civitate Dei), Parte II, XIX, 15-16, p. 405-407. See also J. M. Rist, Augustine - Ancient Thought Baptized, p. 236-239 (exploring also the topic in the Ennarationes in Psalmos). See also G. E. M. de Sainte-Croix, Early Christian Attitudes to Property and Slavery, in: D. Baker (ed.), Studies in Church History, p. 1-38; P. Garnsey, Ideas of Slavery from Aristotle to Augustine, 1996, especially p. 206-219. For references on Augustine's and Patristic views on slavery, cf. E. Flaig, Sklaverei, in: J. Ritter und K. Gründer (Hrsg.), Historisches Wörterbuch der Philosophie, col. 978-979; R. Klein, Sklaverei IV. Alte Kirche und Mittelalter, in: Theologische Realenzyklöpedie, p. 380-381.

27 See again R. Klein, Sklaverei IV. Alte Kirche und Mittelalter, p. 382. 
human utility and good consequence - and the Augustinian picture of servitude: slavery as a human institution is or can be opportune, just, and even necessary in a practical sense for those who live in sin and malice or for those who have limitation in reason, being then a true benefit for these persons to be guided by rational - wiser - persons ${ }^{28}$.

After the issuing in 1537 of the Bulle Sublimis Deus by Pope Paul III and the critical reception of Aristotle's Politics by masters of Francisco de Vitoria's generation and beyond ${ }^{29}$, and more specifically after the debates between Bartolomé de Las Casas and Juan Ginés de Sepúlveda on the juridical claim of just wars of conquest against the barbarians and infidels of the New World, theories of natural slavery modeled after Aristotle were strictly speaking rejected by Catholic intellectuals ${ }^{30}$, as well as by Baroque and early-modern (also "secular") thinkers in general31, or at least defended in much more diffuse and attenuated ways (for example,

28 See Thomas de Aquino, Summa theologiae, l, q. 96, a. 4, resp., p. 472; lallae, q. 94, a. 5, ad 3, p. 429; Ilallae, q. 57, a. 3, ad 2, p. 279; III, suppl. 52, a. 1, p. 163-164 (also aa. 2-4, p. 164-167). See also J. Finnis, Aquinas - Moral, Political, and Legal Theory, p. 184-185; P. E. Sigmund, Law and Politics, in: N. Kretzmann and E. Stump (eds.), The Cambridge Companion to Aquinas, p. 222-228; L. A. De Boni, Ética e escravidão na Idade Média, in: De Abelardo a Lutero. Estudos sobre filosofia prática na Idade Média, p. 324-329.

29 See again R. H. Pich, Dominium e ius: sobre a fundamentação dos direitos humanos segundo Francisco de Vitoria (1483-1546), p. 376-401 (also p. 378, footnote 2). Cf. footnote 6, above.

30 For useful notes about slavery in the thought of Reformed thinkers and, furthermore, in Protestant forms of Christian confession and culture, cf. E. Flaig, Sklaverei, col. 980-981; D. Turley, Sklaverei V. Reformation bis Neuzeit, in: Theologische Realenzyklopädie, p. 383-393 (with rich bibliography in p. 393). See also M. Kaufmann, Slavery between Law, Morality, and Economy, in: M. Kaufmann and A. Aichele (eds.), A Companion to Luis de Molina, p. 191-192.

${ }_{31}$ Cf. in this regard R. Blackburn, The Making of the New World Slavery. From the Baroque to the Modern 1492-1800, 1997. Notes on the accounts and theories of slavery by modern authors such as Jean Bodin, Thomas Hobbes, and John Locke, as well as Enlightenment philosophers such as Montesquieu and Rousseau, can be found in: S. L. Esquith and N. D. Smith, Slavery, in: E. Craig (ed.), The Routledge Encyclopedia of Philosophy, Vol. 8, p. 804-805; E. Flaig, Sklaverei, p. 980-983. Cf. John Locke, Two Treatises of Government, 1960 (originally 1689/1690), I, 1, i. 
as a matter of current, and not permanent state of people) $)^{32}$. A strict abolitionist conviction in Western thought - condemning both natural and civil forms of slavery as morally wrong ${ }^{33}-$, was reached first in the $19^{\text {th }}$ century ${ }^{34}$. It is worth mentioning that the Catholic Church published only in 1839 an official document, the Apostolic Letter In Supremo Apostolatus, by Gregory XVI, condemning slavery as a social institution, and particularly every form of slave trade ${ }^{35}$ - where the focus of condemnation was black slavery. In fact, the last two remarks regard above all black slavery, which, in the broad space of transatlantic relationships between Africa and the Americas, became an institution in the $16^{\text {th }}$ century ${ }^{36}$.

32 That does not mean, of course, that indigenous people on the Spanish and Portuguese sides of Latin America were not enslaved or no longer remained enslaved for other (civil, legal, and economic) reasons until the $18^{\text {th }}$ century; cf. J. O. Beozzo, As Américas Negras e a História da Igreja: questões metodológicas, in: Escravidão negra e História da Igreja na América Latina e no Caribe, p. 43-64. On the so-called "transition" from the slavery of indigenous people to the slavery of Africans in colonial Brazil, cf. S. Schwartz, Escravidão indígena e o início da escravidão africana, in: L. M. Schwarcz e F. Gomes (orgs.), Dicionário da escravidão e liberdade, p. 216-222.

33 On abolitionism in $19^{\text {th }}$ century Brazil, see J. Nabuco, O abolicionismo, 1988, p. 25-29. An important philosophical treatment of slavery in $20^{\text {th }}$ century philosophy was offered by J. Rawls, A Theory of Justice, p. 158ff., $325 \mathrm{ff}$.

34 As it turns out, through the influence of thinkers of the Enlightenment, after the French Revolution (1789-1799) and the Declaration of the Rights of Man and of the Citizen (1789), slavery was abolished in France on February 03, 1794, in the National Convention. But this measure did not relate to slavery in the French colonies around the world. Only in the second half of the $19^{\text {th }}$ century both the practice of slave trade and the social institution of slavery - lastly in Cuba and Brazil - were finally abolished in the Western World. Cf. the studies contained in: F. de Solano y A. Guimerá (eds.), Esclavitud y derechos humanos. La lucha por la libertad del negro en el siglo XIX, 1990. Cf. also R. J. Scott (ed.), The Abolition of Slavery and the Aftermath of Emancipation in Brazil, 1988; M. Maestri, A servidão negra, 1988, especially p. 7-39; M. Maestri, $\mathrm{O}$ escravismo no Brasil, ${ }^{10} 2002$. The mandatory reading about black slavery and abolitionism in Brazil is now L. M. Schwarcz e F. Gomes (orgs.), Dicionário da escravidão e liberdade, 2018, containing fifty critical essays.

35 Cf. J. F. Maxwell, Slavery and the Catholic Church, 1975; E. Vila Vilar, La postura de la Iglesia frente a la esclavitud, in: F. de Solano y A. Guimerá (eds.), Esclavitud y derechos humanos. La lucha por la libertad del negro en el siglo XIX, p. 25-32.

${ }_{36}$ See D. Turley, Sklaverei V. Reformation bis Neuzeit, in: Theologische Realenzyklopädie, p. 384ff.; H. S. Klein, Escravidão africana - América Latina e Caribe, p. 33-104; M. Zeuske, Sklaven und Sklaverei in den Welten des Atlantiks 1400-1940. Umrisse, Anfänge, Akteure, Vergleichsfelder und Bibliographien, p. 97-264 (on the beginnings of slavery in the Atlantic, 1415-1570); M. Zeuske, Sklavenhändler, Negreros und Atlantikkreolen. Eine Weltgeschichte des Sklavenhandels im atlantischen Raum, p. 296-348. 
Closely connected to traditional accounts of reasons for civil enslavement of human beings - that is, of slavery (i) as a consequence of an allegedly just war, (ii) as a form of payment for debts or punishment for crimes, (iii) as a condition inherited by descendants by means of birth, and (iv) as a result of both self- and others-imposed enslavement in extremis-, we face now, with the slavery of blacks, a basic new kind of slavery in the sense of the combination of the following several characteristics: as the status of being someone else's property and a merchandise or a market good, and thus, and particularly, the property both of traders and holders for purposes of massive economic production on national and international (also transoceanic) scales. At any rate, other forms of labor and house services, related to slavery-based societies ${ }^{37}$, remained. There is, however, at this point, a striking "mental" situation concerning slavery that cannot be easily grasped. In a sense, the same generations of thinkers who rejected the natural slavery of Indians and attempted to liberate indigenous peoples also from civil forms of servitude, indulged African slave trade and black slavery in general. Was it really so? How was that possible? What are the philosophical characteristics of their theoretical accounts? What are the features of their practical concerns and their "applied ethics"?

Among the first authors that systematically reflected on black slavery, accordingly, were Domingo de Soto O.P. (1494-1560) ${ }^{38}$, Fernando Oliveira O.P. (1507-1581), Tomás de Mercado (1525-1575), the jurist, active in Mexico, Bartolomé de Frías y Albornoz (ca. 1519-1573), as well

\footnotetext{
37 See H. S. Klein, Escravidão africana - América Latina e Caribe, p. 11-57; E. Vila Vilar, Hispanoamerica y el comercio de esclavos, p. 213-238.

${ }_{38}$ On the positions by Las Casas, who later changed his early favorable view on black slavery, coming to condemn the injustice of the slave trade, cf. the excellent study by M. Méndez Alonzo, From Slave Driver to Abolitionist: Bartolomé de Las Casas on African Slavery, in: Patristica et Mediaevalia, p. 17-28.
} 
as Francisco García (1525-1585) ${ }^{39}$. But there is a consensus that the Jesuit Luis de Molina (1535-1600) was the first intellectual to consider the topic of black slavery extensively, and after him many others such as Fernando Rebello S.J. (1546-1608), Tomás Sánchez S.J. (1550-1610), Alonso de Sandoval S.J. (1576-1652), and Diego de Avendaño S.J. (1594-1688)40. In order to systematically explore the normative treatment Scholastic thinkers - especially "Salmantine" thinkers lato sensu or indirectly - made of black slavery, usually placing the problem of slavery within the broad discussion of moral conscience and, more narrowly, within the questions on the nature and justice of trade and contracts, I propose two stations of research and analysis that might also be helpful for every future study.

Beginning with the analysis of just titles for slavery and slavery trade proposed by Luis de Molina, I make the attempt of showing how his accounts were critically reviewed by Diego de Avendaño, revealing basic features of Second Scholastic normative thinking in Europe and the Americas. Normative knowledge provided by these two Scholastic intellectuals would be deeply tested throughout the last decades of the $17^{\text {th }}$ century, especially by authors - such as the "outsiders" and committed missionaries Francisco José de Jaca O.F.M. Cap. (ca. 1645-1689) and

\footnotetext{
39 See Dominicus de Soto, De iustitia et iure, Lugduni, 1559, lib. IV, q. 2, a. 2; Fernando Oliveira, Arte da guerra do mar, Coimbra, 1555, I, cap. 4; Tomás de Mercado, Summa de tratos y contractos, Sevilla, 1587, lib. II, cap. 20; Bartolomé Frías de Albornoz, Arte de los contractos, Valencia, 1573, lib. II, tit. 2; lib. III, tit. 4; Francisco García, Parte primera del tratado utilísimo y muy general de todos los contractos, cuantos en los negocios humanos se suelen ofrecer, Valencia, 1583. Interesting references can be found in: F. Moreno Rejon, Historia de la teología moral en America Latina. Ensayos y materiales, p. 58-70. See also D. B. Davis, The Problem of Slavery in Western Culture, p. 187-190; Ch. R. Boxer, A igreja militante e a expansão ibérica: 1440-1770, p. 45-53; J. AndrésGallego, La esclavitud en la América española, p. 32-35; L. F. Restrepo, Colonial Thought, in: S. Nuccetelli - O. Schutte - O. Bueno (eds.), A Companion to Latin American Philosophy, p. 39-42.

40 See Ludovicus Molina, De iustitia et iure, Venetiis, 1611, tract. II, disp. 32-40; Thomas Sanchez, Consilia seu opuscula moralia, Lugduni, 1634, lib. I, cap. 1, dub. 4; Ferdinandus Rebello, Opus de obligationibus iustitiae, religionis et caritatis, Lugduni, 1608, lib. I, q. 10, sect. 1-2; Alonso de Sandoval, De instauranda Aethiopum salute, Madrid, 1627 / 1647; Didacus de Avendaño, Thesaurus indicus, Tomus I, Antuerpiae, 1668, tit. 9, cap. 12, §8, nn. 180-205. See also J. Andrés-Gallego, La esclavitud en la América española, p. 35-42; F. R. Montes d'Oca, O discurso antiescravista de Epifanio de Moirans sobre os títulos de escravidão, in: Síntese: Revista de Filosofia, p. 280-283. Further literature about Molina's and Avendano's accounts will be mentioned below.
} 
Epifanio de Moirans O.F.M. Cap. (1644-1689) - who sharpened the systemic analysis and a rigorist moral assessment of every title of slavery and slaveholding, as well as the several requirements of an ethics of restitution.

\section{The Basic Structure of Evaluating Enslavement Titles: Luis de Molina}

Luis de Molina's influential - exclusively normative ${ }^{41}$ - assessment of black slavery can be found in his De iustitia et iure, Book I, Treatise II, Disputations $32-40^{42}$. Treatise II, which contains 760 disputations, is about "commutative justice concerning external goods," and it nearly comprises the half of the six volumes of De iustitia et iure (1593-1609)43. According to Kaufmann, the whole Treatise presupposes a comprehensive definition of ius which makes reference to the later idea of "subjective right" indeed: ius is "a faculty to do something, to receive something, to maintain something or to act in any way, so that whomever hinders the one who has it without legitimate reasons, is doing him a legal wrong, an injustice. Understood in this way, ius is quasi a measure of injustice" ${ }^{\prime 4}$. In fact, several kinds of rights

\footnotetext{
41 See M. Kaufmann, Slavery between Law, Morality, and Economy, p. 189-190, 193, 201.

42 Luis de Molina, De iustitia et iure, ed. Marci Michaelis Bousquet, Coloniae Allobrogum, 1738 (1611), pp. 86-117 (this is the edition I use in this study). In fact, Molina was university professor of philosophy and theology in Coimbra and Évora (Portugal), and later taught in Cuenca (Spain). At any rate, his belonging to the "School of Salamanca" - regarding the methodology of formation and study and the structure of academic production, as well as the characteristics of topics developed and problems discussed - does not need to be discussed again; cf. D. Simmermacher, Natürliche Freiheit und Verantwortung - Dominium bei Luis de Molina, in: M. Kaufmann und J. Renzikowski (Hrsg.), Freiheit als Rechtsbegriff, p. 153, also footnotes 1 and 2.

43 M. Kaufmann, Slavery between Law, Morality, and Economy, p. 183. In this part of Molina's De iustitia et iure we are, thus, dealing with "particular justice", which Aquinas clearly divided into "distributive justice" (iustitia distributiva) and "commutative justice" (iustitia commutati$v a$ ) - in the last case, it is about the justice that regulates over commutationes or "exchanges". See also A. Brett, Luis de Molina on Law and Power, in: M. Kaufmann and A. Aichele (eds.), A Companion to Luis de Molina, p. 159-164.
}

44 M. Kaufmann, Slavery between Law, Morality, and Economy, p. 183. The author translates into English a passage from Molina's De iustitia et iure I, tract. II, disp. I, n. 1. On the idea of subjective rights - i.e., rights that are not based on a given juridical order, but belong to human subjects as such - in Molina's thought, cf. also D. Simmermacher, "Non qua servus est, sed qua homo." Der rechtliche Status von Sklaven bei Luis de Molina, p. 20-28. 
are explained in the sequence of Treatise II. Molina's exposition of the slavery problem, in particular, combines (a) an effort for describing the historical circumstances of enslavement of Africans and the characteristics of slave trade from the African coast to the Western World with (b) a moral-legal analysis of enslavement and slave trade themselves, including an approach to the "subjective rights" of masters and of slaves ${ }^{45}$. The detailed exposition is placed under a theory of dominium proprietatis, that is, a theory about the right of possessing things - in distinction to a theory of dominium iurisdictionis, which is about political power ${ }^{46}$. Slavery is, of course, a kind of property right, implying "an extreme form of dependence and submission"47, as well as a certain loss of freedom. Molina sees in the "freedom" at stake the idea of an internal good, the possession of one's own body and the use of it - usually presupposing that such a possession is claimed and valid within the context of a given human society and political organization. "Honor" (honor) and "fame" or "reputation" (fama) are internal goods, too, and all of them are contrasted to external goods or things which are not oneself or in oneself. In principle, a human being can exert dominium both over internal and external things, and the internal goods just mentioned belong to him according to natural law - Molina affirms that a human being is "lord of his freedom"48. Regarding the ways how a human being can be legally

45 M. Kaufmann, Slavery between Law, Morality, and Economy, p. 184. On the sources of Molina's account, see ibid., p. 190.

46 Luis de Molina, De iustitia et iure I, tract. II, disp. XXXII, p. 86-87. See also A. A. Coxito, Luis de Molina e a escravatura, in: Revista Filosófica de Coimbra, p. 117-136; J. A. Tellkamp, Rights and Dominium, in: M. Kaufmann and A. Aichele (eds.), A Companion to Luis de Molina, p. 125-126, 142-152.

47 M. Kaufmann, Slavery between Law, Morality, and Economy, p. 184.

48 Luis de Molina, De iustitia et iure I, tract. II, disp. XXXIII, n. 14, p. 89: "Tertius titulus est. Emptio et venditio. Ponendumque in primis est, hominem, sicut non solum externorum suorum bonorum, sed etiam proprii honoris et famae est dominus, ut tractatu 4. ostendimus: sic etiam dominium esse suae libertatis, atque adeo stando in solo iure naturali, posse eam alienare, seque in servitutem redigere". On freedom as fundamental, natural, good, as well as on the development of the idea of freedom as a civil and human right in medieval, early-modern, modern and contemporary thought, see M. Kaufmann und J. Renzikowski, Einleitung - Freiheit als Rechtsbegriff, in: M. Kaufmann und J. Renzikowski (Hrsg.), Freiheit als Rechtsbegriff, p. 9-14; M. Kaufmann, Welches Eigentum gehört zum Menschenrecht auf Freiheit?, in: M. Kaufmann und J. Renzikowski (Hrsg.), Freiheit als Rechtsbegriff, p. 117-124. Cf. also D. Simmermacher, Natürliche Freiheit und Verantwortung - Dominium bei Luis de Molina, p. 158-160. 
deprived of dominium over himself in terms of the possession of his body for the sake of free use of it, becoming someone else's property ${ }^{49}$, Molina initially proposed a basic, quite traditional, set of conditions ${ }^{50}$, which might on a normative level, either due to offenses against law or on the basis of legal possibilities, legitimate someone's enslavement: enslavement might be (i) the result of corrective justice because of a bellum iustum, where death penalty is converted into social death or perpetual enslavement ${ }^{51}$; (ii) a form of alternative punishment for a momentous "crime" (propter delitum) that would otherwise be most severely punished ${ }^{52}$; (iii) a condition that would result from a father selling - in a situation of most grave need - either himself or a member of his family (say, his child or children), that is, selling an in principle "free person", where for a just price in that selling-and-purchasing relationship (emptio et venditio) someone's freedom is sold and his or her slavery is bought ${ }^{53}$; (iv) a condition caused by simply being born from an enslaved person or, more exactly, from an enslaved woman (ex matre ancilla), since "birth follows the condition of the womb" 54 .

The (i) first condition, which, despite different accents, is in line with Vitoria's accounts of just war ${ }^{55}$, presupposes as iustae causae the breaking or offending accorded principles of the law of peoples ${ }^{56}$. It

49 Luis de Molina, De iustitia et iure I, tract. II, disp. XXXII, p. 86-87. Cf. D. Simmermacher, Natürliche Freiheit und Verantwortung - Dominium bei Luis de Molina, p. 163-164.

5o According to M. Kaufmann, Slavery between Law, Morality, and Economy, p. 194, the four titles to be now mentioned "[...] have more or less belonged to the tradition since Roman times, [...]".

51 Luis de Molina, De iustitia et iure I, tract. II, disp. XXXIII, nn. 1-3, p. 87-88. On Molina's views on the ius gentium and differences of his account in comparison to Francisco de Vitoria's, see A. M. Hespanha, Luís de Molina e a escravização dos Negros, in: Análise Social, p. 937-960. See also J. M. A. A. Fernandes, Luis de Molina on War, in: M. Kaufmann and A. Aichele (eds.), $A$ Companion to Luis de Molina, p. 227-255.

52 Luis de Molina, De iustitia et iure I, tract. II, disp. XXXIII, nn. 4-13, p. 88-89.

53 Luis de Molina, De iustitia et iure I, tract. II, disp. XXXIII, nn. 14-31, p. 89-91.

54 Luis de Molina, De iustitia et iure I, tract. II, disp. XXXIII, n. 32, p. 91.

55 Cf. footnotes 6,8 , and 25 , above.

56 J. M. García Añoveros, Luis de Molina y la esclavitud de los negros africanos en el siglo XVI. Principios doctrinales y conclusiones, in: Revista de Indias, p. 311; M. Kaufmann, Slavery Between Law, Morality, and Economy, p. 544. 
might be a measure of justice, by the offended side - at least when the offending side is not a Christian nation -, in order to restore just peace after a just war, that people captured have their death penalty converted into "perpetual servitude"57. It has been noticed that Molina offers an etymological explanation for the word "servus" (from "servando"), namely by reminding us of the tradition that "emperors" as highest military commanders - martial judges - might "save" someone's life by commuting death for bondage ${ }^{58}$. As regards the (ii) second condition, it should be mentioned that Molina analyzed a large number of traditional and new "types of delicts considered to be sufficient justifications for enslavement," as well as crimes about which it was not clear whether they should apply individually or collectively (that is, crimes where others might be indirectly involved). He also made considerations about misdeeds - such as a rebellion within a kingdom - on which one might wonder whether they should be treated "according to criminal law or the ius gentium"59. Regarding the (iii) third title, which Molina explains in many details, and presupposing what has been said above about "freedom" as an internal good and a "subjective right" any (adult) human being in principle fully has, our master essentially describes, among and beyond several conditions predicted in "Roman Law" (ius Caesareum) regarding the person to be sold and the terms of the purchase, how we should understand the "most grave" need as an imminent risk of death because of "poverty" (paupertas), "want" (egestas) or equivalent situations. It has been argued that Molina's emphasis on a human being's own possession of his freedom had the effect of being more concessive regarding self-enslavement due to "most grave" (gravis, gravissima), though not "extreme" (extrema),

57 Luis de Molina, De iustitia et iure I, tract. II, disp. XXXIII, p. 88. See also M. Kaufmann, Slavery between Law, Morality, and Economy, p. 195-196.

${ }^{8}$ Luis de Molina, De iustitia et iure I, disp. XXXII, tract. II, p. 86. "Mancipium" derives from "manucapta", that is, "hands caught", meaning that a life form in bondage is better than death.

59 M. Kaufmann, Slavery between Law, Morality, and Economy, p. 196. See Luis de Molina, De iustitia et iure I, tract. II, disp. XXXIII, p. 88-89. 
necessity ${ }^{60}$. At any rate, the commutation of most radical poverty for a slavery contract by means of purchase might be viewed as a charitable solution - and enslavement, here, did not need to be perpetual, so that freedom might be regained after financial or material compensation ${ }^{61}$. About the (iv) fourth title, although Molina takes it just as a positive law of the ius gentium and is aware of legal variances of it in different nations, he allows for a child born from an enslaved woman to follow her civil condition, too - at the end, it is about the civil condition of the mother, not of the father, that one may be totally sure. He seems to accept that, if the mother was free at any moment from conception to birth, that interval of freedom would be enough to grant the child's freedom, although he also considers the customary law according to which, for that very same purpose, the mother would have to be free at the moment of birth ${ }^{62}$.

In fact, the emphasis, now, in Molina's explanations lies on the fact that an enslaved person becomes someone's property through purchase within a trade system. For him, the relational notion of "being a property" - it obviously presupposes a "possessor" - needs further determination as long as the nature of the possessed thing is concerned. Being the owner of a human being through purchase does imply possessing his liberty, but it does not imply possessing his life. It allows the possession of someone's body for a conditional use, that is, for forcefully working for his owner, as well as the possession of the fruits of their work, other incomes obtainable from them and children born by enslaved women. But a slaveholder has no ownership over the physical and spiritual health of someone's body, what implies that the holder is not allowed to dispose ad libitum of a slave's limbs and any further item the very life of the slave depends upon ${ }^{63}$. The explanation of the scope

\footnotetext{
6o M. Kaufmann, Slavery between Law, Morality, and Economy, p. 198.

${ }_{61}$ Luis de Molina, De iustitia et iure I, tract. II, disp. XXXIII, p. 90-91. See also M. Kaufmann, Slavery between Law, Morality, and Economy, p. 197-201.

62 Luis de Molina, De iustitia et iure I, tract. II, disp. XXXIII, p. 91.

${ }^{63}$ Luis de Molina, De iustitia et iure I, tract. II, disp. XXXVIII, nn. 2-3, p. 110.
} 
of the dominium proprietatis in question is important to help drawing ethical principles for any master-slave relationship ${ }^{64}$, especially in what regards good treatment, good nourishment and further restrictions of abuses, excessive work, and unjust punishment by the master -, in a nutshell: there are many deeds a master is morally and legally not allowed to do against the slave, after all the slave has rights qua homo. Public authorities are entitled to protect the rights of the slaves in those cases - "insofar as they are human beings and our next" (qua homines ac proximi sunt) -, and it might be the case that holders would have to compensate them ${ }^{65}$. As a whole, following the judgment by Kaufmann, Molina seems to be much more committed to the "protection of the slave against arbitrary treatment by his master" as it happened in the tradition of Roman law ${ }^{66}$. At any rate, since any "labor" and "ownership ethics" depends on the justice of slave trade in the first place, it is on the correctness of trade and purchase contract that Molina's exposition focuses. It is undeniable that what essentially concerned Molina was (a) the analysis of the justice of the ownership of slaves in the context

64 Luis de Molina, De iustitia et iure I, tract. II, disp. XXXVII-XXXIX, p. 107-113.

65 Even deprived of natural freedom (in the sense of living then under the rulership and being property of other human being(s)), as well as of legal freedom, slaves keep their status as subjects of rights due to their natural dominium over themselves (their human status as beings capable of making use of reason and will); (f. D. Simmermacher, Natürliche Freiheit und Verantwortung - Dominium bei Luis de Molina, p. 165-168. See Luis de Molina, De iustitia et iure I, tract. II, disp. XXXVIII, 1-4, p. 110-111; here n. 4, p. 111: "Quamvis autem leges hae, quia si excusserit servo aut ancillae, similiter iudiciales erant, cessaverint, aequitate tamen nitebantur, tenenturque hodie naturae iure, qui similia crimina in servos suos commiserint, satisfactionem competentem servis ipsis efficere, qua homines ac proximi sunt, et quatenus damnum et iniuria in eos quoad ea, quae dominorum potestati minime subsunt, redundat". See also M. Kaufmann, Slavery between Law, Morality, and Economy, p. 218-221.

${ }_{66}$ M. Kaufmann, Slavery between Law, Morality, and Economy, p. 220. On the topic of the dominium the slave has over some things (the scope of his property rights) and the theme of the possibility of friendship and justice between slave and master, see ibid., p. 220-221, as well as Luis de Molina, De iustitia et iure I, tract. II, disp. XXXVIII, n. 5, p. 111-112. In fact, as long as master and slave are compared according to these two opposite legal status, there is neither friendship nor justice between them; however, as they are compared to each other as human beings, there is both friendship and justice between them indeed (in their contract). See Luis de Molina, De iustitia et iure I, tract. II, disp. XXXVIII, n. 5, p. 111: "Licet enim domini comparatione servi, ea ratione qua servus est, neque amicitia, neque iustitia sit: ea tamen ratione, qua homo est, utrumque esse potest, ut Aristoteles 8. Ethicorum capit. 11. affirmat. Quo fit, ut tunc dominus stare teneatur contractui, nequer usurpare possit, quae sibi servus eo modo comparavit". 
of slave trade and therefore (b) the justice or licitness of slave trade itself. Until the $18^{\text {th }}$ century, this double approach is paradigmatic for most Baroque scholastic texts that morally evaluated black slavery. And for Molina those two inquiries regarding the licitness of slavery had to be carried within the context of the commercial activities by the Portuguese in the jurisdictional space of the Portuguese crown. In particular, the disputes on black slavery by Molina and other explanations influenced by him (i) focused first on the moral duty by merchants who were engaged in that multi-linked business chain, that is, who bought slaves from first-hand sellers on the African coast and transported them to the West - where those sellers, on their turn, might be "international" merchants or African slaveholders themselves ${ }^{67}$. And (ii) they focused second on the moral duty by holders who bought and then possessed slaves in Europe and above all in the New World ${ }^{68}$. Putting it simply: any merchant who through purchase or trade became possessor of slaves had the moral duty of checking the validity of any title before buying and offering slaves on the market; and any initially bona fide owner of slaves who came to doubt about their enslavement titles had the moral duty of checking the status of the purchased items and the purchase. To be sure about the justice of the slavery status of enslaved Africans was a moral obligation: "safe conscience" (conscientia tuta) against "capital sin" (culpa lethalis) by merchants, purchasers, and owners regarding that status is mandatory in the first place, and this requirement characterizes all normative evaluations from Molina onwards ${ }^{69}$.

In order to provide a clear - and well-informed - moral judgment about the emptio et venditio of enslaved Africans in the first link of the business

\footnotetext{
67 Luis de Molina, De iustitia et iure I, tract. II, disp. XXXV, p. 97-106.

68 Luis de Molina, De iustitia et iure I, tract. II, disp. XXXVI, p. 106-107.

69 Luis de Molina, De iustitia et iure I, tract. II, disp. XXXV, nn. 1-2, n. 8, p. 98-99, 100; here n. 1, p. 98: “[...]: qui, facta prius diligenti ac certa inquisitione de titulis ac modis, quibus re ipsa eiusmodi homines in captivitatem rediguntur, captivique asportantur, statuant, quid iuste, et quid iniuste fiat, quidque facto opsu sit, ut tam regis conscientia, quam negotiantium, mancipiaque a negotiantibus ementium, tuta sit". See also M. Kaufmann, Slavery between Law, Morality, and Economy, p. 207-208.
} 
chain, Molina makes a detailed report of how slave trade on the African coast - also in today's Mozambique and in several Asian regions - originally began and was continuously practiced. By so doing, he helped to historically and geographically understand the commerce of slaves from Upper Guiena down to Lower Guinea and Angola, especially in what regards the deals by Portuguese traders with inhabitants of the West-African coast ${ }^{70}$. Especially, Molina describes the role of the king(s) of Angola and the local leaders called "sobas" in establishing commercial relationships with the Portuguese which put the structure to future slave trade routes with the Western world ${ }^{72}$. At the end, the Portuguese, partially with justification, made several specific alliances with sobas who wanted to make opposition to the unloyal Angolan kings and establish their own circle of influence and enrichment: for Molina, several wars were justly waged in those cases ${ }^{73}$. But precisely the sobas allied with the Portuguese created the system of sending enslaved people to the African coast, where they were traded and shipped away. However, Molina was aware that the sobas, who acted as absolute judges in their lands, subjected people to slavery by abusive means, above all by arbitrarily sentencing minor crimes with death penalty and, then, commuting it for enslavement ${ }^{74}$. In this way, a quite large number of people were enslaved and "formally" enabled to be a market product" ${ }^{75}$. The sobas felt free to create an arbitrary system of capital punishment for minor crimes and practiced spurious forms of converting those crimes sentenced to death into enslavement, ending in many "legal" way-outs for bringing sentenced people to be sold to the Portuguese $^{76}$.

\footnotetext{
70 M. Kaufmann, Slavery between Law, Morality, and Economy, p. 201-207.

71 See also $\mathrm{H}$. Joner, Impressions of Luis de Molina about the Trade of African Slaves, in: Patristica et Mediaevalia, p. 39-50.

72 Luis de Molina, De iustitia et iure I, tract. II, disp. XXXIV, p. 91-96.

73 Luis de Molina, De iustitia et iure I, tract. II, disp. XXXIV, nn. 8-14, p. 93-96.

74 Luis de Molina, De iustitia et iure I, tract. II, disp. XXXIV, nn. 3-14, p. 92-95.

75 Luis de Molina, De iustitia et iure I, tract. II, disp. XXXIV, n. 14, p. 95.

${ }_{76}$ Luis de Molina, De iustitia et iure I, tract. II, disp. XXXIV, nn. 11-14, p. 94-96.
} 
At any rate, (i) Molina accepts that merchants buy slaves, without any need of further examination, from places where the Portuguese had been engaged in wars justly waged - even after such wars had ended and under the assumption that people in question were enslaved because of the war or were "offspring of women legitimately enslaved"77. Moreover, (ii) in some places such as in both Guineas it seemed permissible to buy slaves, that is, people who were sentenced to slavery after all, due to arguably grave felonies according to the local laws. However, Molina was aware that there were many cases in which people were sentenced so through spurious processes and because of unacceptable reasons indeed, for example because of crimes committed by others to whom it just happened that they had some kind of relationship and, again, light and ridiculous crimes such as stealing objects of minor value ${ }^{78}$. (iii) Regarding, once more, the important topic of the right a person has of selling himself or his freedom, or, in the case of a father, his children or their freedom, Molina offers careful examinations of cases where the normative criterion of licitness (the existence of a great need) and the normative criterion of illicitness (sale of freedom "extra necessitatem") are tested against historical human facts - in many cases, however, Molina believes that the enslavement of infidels and / or children of infidels is useful indeed both for the buyer and the physical and spiritual health of those whose freedom is bought ${ }^{79}$. But if such a commerce is to be done at all, Molina is, regarding every title, quite sensitive to the question about the price offered for somebody's freedom - devalued sales are done already by African holders, "who sell slaves for

\footnotetext{
77 Luis de Molina, De iustitia et iure I, tract. II, disp. XXXV, nn. 3-4, p. 99. See also M. Kaufmann, Slavery between Law, Morality, and Economy, p. 208.

78 Luis de Molina, De iustitia et iure I, tract. II, disp. XXXV, nn. 5-8, p. 99-100.

79 Luis de Molina, De iustitia et iure I, tract. II, disp. XXXV, nn. 9-12, p. 100-101. See also M. Kaufmann, Slavery between Law, Morality, and Economy, p. 208-210. At any rate, Molina (ibid., n. 9-10, p. 100) seems to concede that parents and even their children, if they are "old" or "intelligent enough" (doli capaces) and, thus, capable of making contracts, are owner of their free will and freedom to the point of, without grave necessity, selling themselves; this is as such a $\sin$. But if that happened in a (foreign) land where such a contract was allowed, the contract will be valid for the purpose of trading slaves or putting them on the market.
} 
such worthless things as elephant hair or leopard's teeth"80. In order to criticize purchases under all too cheap pretia, especially of children, Molina usually appeals to moral and Christian conscience, hesitating, however, "to use legal coercion against the owners" of "cheap slaves"

At any rate, as his fourth conclusion explicitly shows, (iv) Molina thought, in fact, that most likely the entire slave trade was illicit from the beginning: those engaged in it are in mortal sin and will receive eternal damnation ${ }^{82}$. In particular, the merchant as a purchaser had to be certain of the fairness regarding the slave as sold item (it had to be justly enslaved) and regarding the selling (it had to be a just action by a legitimate owner): if justice did not obtain in any of those cases, then the purchaser could not possibly be a legitimate new owner either. Molina expressed the influential opinion that, although "invincible ignorance" - and, thus, the existence of bona fide traders and holders - might be theoretically conceded, regarding the necessary knowledge of the justice of any enslavement all merchants either knew that the original enslavement and the first selling-and-purchasing were illegal or they did not make any relevant effort to verify the justice of the alleged original status of the "products" - they did not care about the fairness of their origin. So, for example, everyone knew that those enslaved persons were not put into that condition as a consequence of just wars according to the ius gentium, but rather quite explicitly just robbed or captured ${ }^{83}$. Since the

8o M. Kaufmann, Slavery between Law, Morality, and Economy, p. 211. See Luis de Molina, De iustitia et iure I, tract. II, disp. XXXV, n. 12, p. 101-102 (here p. 101).

${ }_{81}$ M. Kaufmann, Slavery between Law, Morality, and Economy, p. 212: "He [Molina] is obviously reluctant to use legal means to intervene in market processes, even when, from a moral point of view, he seriously condemns the outcome of these processes".

82 Luis de Molina, De iustitia et iure I, tract. II, disp. XXXV, n. 16, p. 103: "Mihi longe verisimilius est, negotiationem hanc ementium eiusmodi mancipia ab infidelibus illis in locis, eaque inde asportantium, iniustam, iniquamque esse, omnesque qui illam exercent, lethaliter peccare, esseque in statu damnationis aeternae, nisi quem invincibilis ignorantia excuset, in qua neminem eorum esse affirmare audere".

${ }_{83}$ Luis de Molina, De iustitia et iure I, tract. II, disp. XXXV, nn. 16-18, p. 103-105; here n. 18, p. 104: "Quod de Aethyopum bellis, quibus ordinarie capiunt mancipia, quae Lusitanis vendunt, praesumendum esse arbitror (iuxta ea, quae mercatores ipsi, nulla tormentorum vi coacti, dum 
rumors about the unfairness of the trade were widespread, practically speaking the need of previous certification of the status of slavery was an obligation ${ }^{84}$ to every merchant. As a consequence, either in one case or the other, traders acted in bad faith: either they had knowledge that what they did was wrong or they acted in doubt or vincible ignorance ${ }^{85}$.

Under these presuppositions, it must be stressed that Molina, just like others after him - though with different accents and interpretations -, affirmed that merchants and purchasers, having properly confirmed, after a morally mandatory investigation, that the status of the product they acquired was illicit or doubtful still, were morally obliged to restitution: (a) in principle, traders had to investigate and be sure of the slavery status before buying slaves (otherwise the commerce was illicit) ${ }^{86}$; (b) if doubts later arose, and through mandatory investigation a trader came to know about the illicitness of enslavement, he was obliged to immediate restitution of freedom - this is valid for any kind of slaveholder, irrespective of his distant position in the chain of trade and ownership, of the time passed since he became an owner and even of the price he spent with the "product." In most cases, restitution would imply the compensation for services rendered and according to the measure of benefit and enrichment by the holders, as well as compensation for bad treatments, offenses and damages suffered - to

interrogantur, respondent) est, potius illa esse latrocinia, quam bella". See also M. Kaufmann, Slavery between Law, Morality, and Economy, p. 213-224; L. B. Rout, Jr., The African Experience in Spanish America. 1502 to the Present Day, p. 404; R. Blackburn, The Making of the New World Slavery. From the Baroque to the Modern 1492-1800, p. 602; A. Saunders, A Social History of Black Slaves and Freedmen in Portugal, 1441-1555, p. 283.

${ }^{84}$ In fact, whenever Molina talks of "obligatio" in such texts (or similar expressions, such as the use of the verb "tenere") there is a double perspective: on the one hand, the perspective of law, where there are legal obligationes regarding trading and contracts (between trader and customer, for example) - and they are protected and guaranteed by the authorities. On the other hand, there are obligationes in the sphere of conscience, such as the practical knowledge a trader and holder must have in order to act in good faith. Although in many cases these perspectives conflate, Molina many times appeals to the conscience of moral obligation, as, for example, when it is about solving a doubt regarding an enslavement title and, then, his obligation of restituting freedom and further items.

85 Luis de Molina, De iustitia et iure I, tract. II, disp. XXXV, nn. 16-18, p. 103-105.

${ }^{86}$ Luis de Molina, De iustitia et iure I, tract. II, disp. XXXV, n. 19, p. 105. 
enslaved people directly or to their heirs, descendants or relatives ${ }^{87}$. (c) If doubts later arose, and through mandatory investigation an owner was unable to have certainty about the licitness of enslavement or not, he was obliged to some sort of restitution "according to the degree [quantity] of doubt" (pro quantitate dubii) ${ }^{88}$. Molina's account characterizes, thus, a long tradition of Scholastic moralists who carefully discriminate and relate - more or less based on Thomas Aquinas's and the rich commentary tradition on his question on restitution in Summa theologiae llallae q. 62 aa. 1-8 - the several headings under which acts of restitution should take place to the very topic of giving Africans unjustly enslaved a proper restitution (and of punishing those who mala fide traded with them $)^{89}$.

One problematic point, however, is the overall account Molina gives of the principle of property rights according to which "in doubt the condition of the possessor is the better one" (in dubio melior sit conditio possidentis) ${ }^{90}$. In cases of established contracts, the existence of doubt can favor, for example, the owner, and not the freedom of the enslaved person. Molina pays special attention to this theme by evaluating the moral stance of owners in the system of slave trade, particularly those who in Europe or in the Americas bought them bona fide - this is discussed in Disputation 36 of De iustitia et iure I, tract. II. If someone bought a slave - from a merchant or another possessor, who apparently at least saw no reasons for doubting - in the honest belief that the enslavement was fair, that possessor is allowed to keep the slave ${ }^{91}$. Truly, a holder must be persuaded by strong evidences

\footnotetext{
87 Luis de Molina, De iustitia et iure I, tract. II, disp. XXXVI, n. 2, p. 107.

88 Luis de Molina, De iustitia et iure I, tract. II, disp. XXXV, nn. 16-18, n. 20, p. 103-105, 105-106.

89 Luis de Molina, De iustitia et iure I, tract. II, disp. XXXVI, n. 1-5, p. 106-107.

90 The principle is derived from a rule of Roman and medieval law for deciding cases involving doubtful ownership of goods: "In pari delicto vel causa potior est conditio possidentis" (Corpus iuris canonici, Liber Sextus Decretalium lib. V, tit. 12, De regulis iuris, reg. 65). According to the principle, a possessor of a thing cannot be deprived of it as long as the unlawfulness of his possession has not been sufficiently established. See also R. Schüssler, On the Anatomy of Probabilism, in: J. Kraye and R. Saarinen (eds.), Moral Philosophy on the Threshold of Modernity, p. 98-100.

91 Luis de Molina, De iustitia et iure I, tract. II, disp. XXXVI, n. 3, p. 107.
} 
that he possessed an illicit item - what the slaves themselves say is not enough. As a simple citizen, in most of the cases a slave possessor cannot collect all - not even many - evidences needed, not to mention that he cannot have overall control over the system of slavery. Molina seems to indulge in the view that princes or ministers should do that verification for the sake of their citizens", that is, in their jurisdiction they should "control whether the goods that are imported and sold in the kingdom are of trustworthy origin - a very macabre kind of customer protection"93. But if the possessor recognizes that the slave was victimized, he "has to set him free immediately, no matter how much he paid for him"94 (see above). If it happened already some time ago, the same holds, for freedom does not expire because of time - in such a case, the condition of the possessor of freedom is the better one ${ }^{95}$. At any rate, if the owner begins to have doubts, he must investigate; if his bona fides wins, he does not need to continue investigating. He would have, after all, a justifiable invincible ignorance. However, remaining doubts might still motivate a degree of restitution ${ }^{96}$.

Due to the overall widespread doubt regarding the licitness of enslavements and first purchase and ownership and the moral obligation of verifying the licitness of any slave titles, which were in practice impossible to be proved licit, it is fair to affirm that Molina condemns slave trade, although this is not a stance against slavery or the trade of slaves as such - i.e., an endorsement of the principle according to which it is always and everywhere wrong that a human being is a property of another human being -, but against the concrete system he was historically evaluating.

\footnotetext{
92 Luis de Molina, De iustitia et iure I, tract. II, disp. XXXVI, n. 1, p. 106-107.

93 M. Kaufmann, Slavery between Law, Morality, and Economy, p. 215. See Luis de Molina, De iustitia et iure I, tract. II, disp. XXXVI, n. 1, p. 106.

94 M. Kaufmann, Slavery between Law, Morality, and Economy, p. 215. See Luis de Molina, De iustitia et iure I, tract. II, disp. XXXVI, n. 2, p. 107.

95 Luis de Molina, De iustitia et iure I, tract. II, disp. XXXVI, n. 3, p. 107. See also M. Kaufmann, Slavery between Law, Morality, and Economy, p. 215.

96 Luis de Molina, De iustitia et iure I, tract. II, disp. XXXVI, n. 5, p. 107. See M. Kaufmann, Slavery between Law, Morality, and Economy, p. 215.
} 
The practice, thus, was both against Christian charity and, as we have emphasized, against natural and human justice (the law of peoples): it was, simply put, an error or a $\sin ^{97}$. It is also interesting that Molina understood that such a moral-legal error was "systemic" and demanded a systemic correction. After all, although he emphasized the role played by traders in the chain of slavery, every link of it shared some responsibility, such as enslavers in the African continent, first purchasers and sellers on the African coast, but also bishops, priests and rulers, who might have issued official prohibitions and restrictions, but did not ${ }^{98}$. Molina did not explore much the reasons for such a "moral leniency." Although some would say that the system offered the blacks the possibility of catechesis, baptism, and salvation and even some "material benefits" and a civilized life in contrast to barbarism, it was obvious for Molina that, as he says in his (v) fifth conclusion, traders were only interested in profit. At any rate, Molina works with a quite deontological principle according to which "one should not commit misdeeds in order to make good things [or ends] to come" (facienda non sunt mala, ut eveniant bona) ${ }^{99}$.

(To be continued in: Veritas 65:1 (2020))

\section{Endereço Postal}

Escola de Humanidades da PUCRS

Avenida Ipiranga 6681 - Prédio $8-4^{\circ}$ Andar,

Partenon, Porto Alegre - RS, 90619-900

\footnotetext{
97 Luis de Molina, De iustitia et iure I, tract. II, disp. XXXV, n. 16, n. 17, p. 103-104, 105-106.

98 Luis de Molina, De iustitia et iure I, tract. II, disp. XXXV, n. 16, n. 19, p. 103-104, 105.

99 Luis de Molina, De iustitia et iure, I, tract. II, disp. XXXV, n. 19, p. 105. See also M. Kaufmann, Slavery between Law, Morality, and Economy, p. 214.
} 